\title{
Distributed Economies
}

\author{
Aguinaldo dos Santos, Carlo Vezzoli, Brenda Garcia Parra, \\ Sandra Molina Mata, Sharmistha Banerjee, Cindy Kohtala, \\ Fabrizio Ceschin, Aine Petrulaityte, Gabriela Garcez Duarte, \\ Isadora Burmeister Dickie, Ranjani Balasubramanian, and Nan Xia
}

\section{Reframing the Economy Towards Sustainability}

There is an urgent need to reframe the economy towards a new paradigm where economic evolution occurs fairly and ethically, in conjunction with the development of human well-being achieved in harmony with nature. This emerging paradigm presents profound divergences from the orthodox paradigm, which is based on economic rationality (characterized by a continuous pursuit of economic efficiency

\footnotetext{
A. dos Santos $(\varangle) \cdot$ G. G. Duarte

Universidade Federal do Paraná, Curitiba, Brazil

e-mail: asantos@ufpr.br

C. Vezzoli

Design Department, Politecnico di Milano, Milan, Italy

B. Garcia Parra - S. Molina Mata

Universidad Autónoma Metropolitana, Mexico City, Mexico

S. Banerjee

Indian Institute of Technology Guwahati, Guwahati, India

C. Kohtala

Department of Design, Aalto University School of Arts, Design and Architecture, Espoo, Finland

F. Ceschin - A. Petrulaityte

Department of Design, Brunel University London, London, UK

I. B. Dickie

Universidade da Região de Joinville (Univille), Joinville, Brazil

R. Balasubramanian

Srishti Institute of Art, Design and Technology, Bengaluru, India

N. Xia

Tsinghua University, Beijing, China
} 
Table 1 Comparing two economic paradigms [57]

\begin{tabular}{l|l}
\hline Orthodox paradigm & Promising sustainability paradigm \\
\hline Individualism & Solidarity \\
\hline Growth & Development \\
\hline Large scale & Small scale \\
\hline Competition & Cooperation \\
\hline Centralization & Distribution \\
\hline Profit & Well-being \\
\hline Tangible & Intangible \\
\hline Product based & Service based \\
\hline Reduced ethics & Ethical and fair \\
\hline Consumerism & Sharing \\
\hline
\end{tabular}

in resource exploitation) $[13,17,39,55,60,66]$. In a sustainable approach, solutions should jointly promote the improvement of welfare, social cohesion and social equity, while significantly reducing environmental impact and resource depletion. Table 1 illustrates the main differences between these economic paradigms.

This new economic paradigm includes cooperative work in the production of goods and services, solidarity finance, fair trade and solidarity consumption (MTE 2012). An initiative or enterprise is guided by the generation of work and income and, at the same time, seeks to achieve social inclusion and respect for ecosystems. The economic, political and cultural results obtained from value creation are shared among participants, thus constituting a strategy to overcome the pattern of subordination and vulnerability observed in conventional practices prevalent in the orthodox economy [27]. The implementation of such a vision has the excessive centralization of the economy as one of its key barriers, as explained in the next section.

\section{How Centralization Hinders Sustainability and Resilience}

The rationale for centralizing, mass production for economies of scale has been based on the ideals of efficiency and cost-savings, ideals that are rarely tested for their real efficiency or efficacy $[11,31,43]$. For example, in the case of electricity, a certain percentage is always lost in transmission, particularly in grids that are not well maintained. Manufacturing of goods by centralized mass production becomes efficient particularly when the social and environmental costs of manufacturing, from waste and pollution to decent working conditions, are externalized. In the worst case, overcapacity may be pushed onto consumers through aggressive marketing as well as planned obsolescence strategies, and nature is seen only a provider of 'resources', raw materials and raw land to be exploited. Much critique of current industrial mass production thus centres on tendencies to promote consumerist values, 
overconsumption and throwaway products. Large firms are also less likely to answer to consumer pressure for environmental and social responsibility; simultaneously, the large distances between consumers and manufacturing supply chains means consumers are not always fully aware of sustainability issues [5].

In the fast fashion industry, for instance, production efficiency, low wages and dangerous working conditions in many regions have radically reduced the prices of apparel for consumers, which in turn has increased consumption-and its negative social and environmental impacts-by even 40\% [46]. Negative environmental impacts from the production of fast fashion include substantial use of water and chemical pollutants, especially in regions of water scarcity and less capacity for environmental protection measures, not to mention impacts from transportation, retail distribution and disposal [46]. Such impacts are usually experienced in low- and middleincome regions far from where the clothing is purchased. Moreover, there are negative environmental impacts from waste in many industries, which includes not only pre-consumer waste produced during manufacturing, but also "deadstock" - finished goods such as fast fashion and luxury goods that are disposed of before they even reach the consumer [45]. Deadstock is surplus output, a direct result of overproduction in centralized, large-capacity, capital-intensive mass production, in contrast to other models such as production-on-demand. The principle of Distributed Economies therefore calls for an analysis of what products and services in a specific region deliver social and environmental harms by virtue of being produced in large-scale, centralized modes. The objective is to become sensitive to and work to change systems that have become an "ever-faster once-through flow of materials from depletion to pollution" $[11,28]$.

Critique of 'centralization' is not limited to tangible products and their manufacturing. In the fast fashion example, attention is also paid to what consumer behaviours are encouraged as a result of low prices in a consumerist society, which impose barriers to other experimental models such as sharing, renting and upcycling that would extend product and material lifetimes. These alternative models also connect actors in other ways than fiat money, connections that are not visible or valued in models that emphasize capital-intensive, efficient, centralized industrial systems $[38,44,54]$. At the same time, one must also be wary of centralizing tendencies in the "sharing economy". As the largest peer-to-peer platforms for "collaborative consumption" gain critical mass, while retaining ownership in centralized corporate hands far from local users, there is uncertainty and controversy over how such "platform capitalism" delivers social benefits, local value and positive environmental impacts for their diverse stakeholders [20, 44, 53, 59].

Another critique of institutional centralizing relevant to design relates to expertise and legitimacy: who has the authority to produce, design, innovate and distribute. Centralized production, geographically and/or via patents and Intellectual Property Rights regimes, separates the authority to repair and maintain from the knowledge to repair and maintain, for instance. Such barriers can affect actors who contribute to a local economy and ensure circular material flows (through product longevity) — such as repair hackerspaces - but are not accounted for in neoclassical economics indicators $[31,54]$. Analysis according to DE principles would therefore examine where 
economic activities threaten local resilience and the ability to satisfy local needs, cases where "one industrial production process exercises an exclusive control over the satisfaction of a pressing need and excludes nonindustrial activities from competition" [29]. It is beneficial for environmental, social and economic sustainability that knowledge of design and abilities to innovate are not removed from communities, but are rather enhanced.

Centralized systems and the accompanying extreme focus on efficiency must thereby be examined in terms of sustainability because of the impact on societies' and systems' resilience. If resilience is understood as the ability for a system (such as a city, region or neighbourhood, including natural systems and industrial systems) to be flexible, agile, adaptive and able to absorb shocks from a disturbance [24, 26, 50], an excessive focus on efficiency leads to structures that are fragile and brittle [50]. Both ecosystems and human systems absorb shocks and deal with disturbances by "allowing the existence of some redundant and not-so-efficient pathways" [9, 50]. From the point of view of a city, resilience would address dependence on global supply networks and the need for diversified economic activities, which requires examination of the role of mass manufacturing and services in the region [24].

The shift to a network society [12] appears to embed new potential: new ways societies can meet their needs and express themselves creatively, which call into question-and actively dismantle_-harmful systems [6]. Walter Stahel suggests shifting emphasis from production optimization to use optimization, and that large-scale, capital-intensive production units be gradually or partially replaced by "smaller-scale labour-intensive, independent, locally integrated work units" [62]. This "distributed" model is the focus of the next section.

\section{Distributed Economies (DE) as a Strategy Towards Sustainability}

Distributed Economies consists of small-scale value-adding units (e.g. manufacturing, services) where there is a shift in the control of core activities towards the user/client. Johansson et al. [31] first defined Distributed Economies as a "selective share of production distributed to regions where activities are organized in the form of small scale, flexible units that are synergistically connected with each other" in a network.

These local units serve local needs near or at the point of use, including artefact and service demands across the product life cycle and business process, shifting the control of essential activities towards or by the end-user, whether individuals, entrepreneurs or organizations. Hence, in such contexts, local units are more capable of offering on-demand solutions and having a higher level of multi-user participation, including those situations where the user her/himself can also take the role of manufacturer or service provider. 
In a Distributed Economy, these small-scale units could be stand-alone or peerto-peer, connected with other nearby units to share various forms of products, semifinished products, resources, knowledge/information and other types of services. These local units are sometimes organized as multiple providers to the same order, forming a much more resilient network (e.g. cooperatives). Hence, this local network can be connected to nearby networks, resulting in an expanded network of networks, i.e. they become a Distributed Economy Network (DEN). If properly designed taking sustainability principles into account, they have potential to promote locally based sustainability, i.e. Sustainable Distributed Economies (S.DE). They share or jointly use various forms of local resources, including skills, knowledge and manufacturing/service capabilities.

When we discuss the concept of Distributed Economies, we do so in contrast to Centralized Economies for simplicity and clarity in analysis. With that in mind, we can identify two types of small-scale locally-based production units where we find a shift in the control of core activities towards the user/client. The first we (also) call Distributed, which are by the end-user, and the second Decentralized, which are nearby the end-user, as illustrated in the diagram below (Fig. 1). ${ }^{1}$

In contrast to DE, a Centralized Economy is characterized by large production units located (often) far from its customers (individuals or organizations), with production capacity geographically concentrated, delivering products/services via large distribution networks. Their large-scale, stand-alone production units demand high control of essential activities and, thus, decision making is often centralized. Due to their scale, implementation of changes is often costly and time-consuming (Fig. 2).

Meanwhile, a Decentralized Economy is characterized by small-scale production units that deliver their goods and services via light distribution networks, directly to customers, whether individuals, entrepreneurs or other organizations/institutions, increasing customers' control over essential activities; they could be stand-alone or connected to each other to share various forms of goods and services. Thus, the cost and time for implementing or changing them is also variable. Their decision-making process is decentralized, with some customer/user control over essential activities (Fig. 3).

Finally, a Distributed Economy involves (very) small-scale production units of goods (physical and/or knowledge-based artefacts) located near or at the same place of the end-users (who become the producers, i.e. prosumers) that have control over essential activities, whether individuals, entrepreneurs or organizations/institutions. They could be stand-alone or peer-to-peer connected to each other to share various forms of goods and services (see Fig. 4).

A Distributed Economy (DE) could be further characterized by its life cycle localization depth, i.e. whether it is centralized, decentralized or distributed along all its life cycle stages (pre-production, production, distribution, use and disposal). The relevance and configuration of these stages could differ from case to case, as exemplified in the right-most diagram in Fig. 5, which describes the life cycle localization

\footnotetext{
${ }^{1}$ We thereby use this terminology and conceptualization in this volume, acknowledging that these terms have different definitions in various fields.
} 
depth of a solar panel produced and distributed by a multinational company (Centralized), installed and used by an individual, e.g. having it installed on the roof of their home (Distributed), and disposed of locally (Decentralized). An in-depth analysis of this example shows the system is Centralized in its pre-production, production and distribution phase, Distributed in its use phase and Decentralized in its disposal phase.

\section{CENTRALIZED TO DECENTRALIZED TO DISTRIBUTED}

STRUCTURE 1 to very many/hierarchical control TO no intermediaries TO peer-to-peer

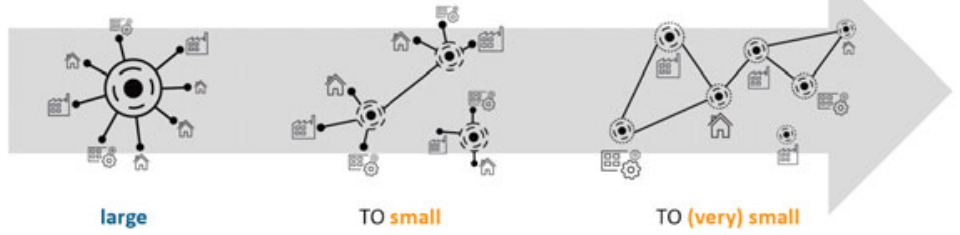

SIZE

Fig. 1 The paradigm shift from centralized, to decentralized, to distributed economies

Fig. 2 The structure of the production unit of Centralized Economies

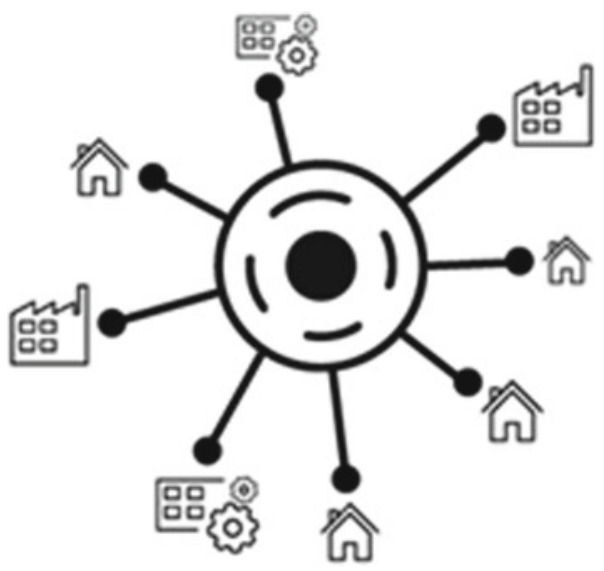

Fig. 3 The structure of the production unit of Decentralized Economies






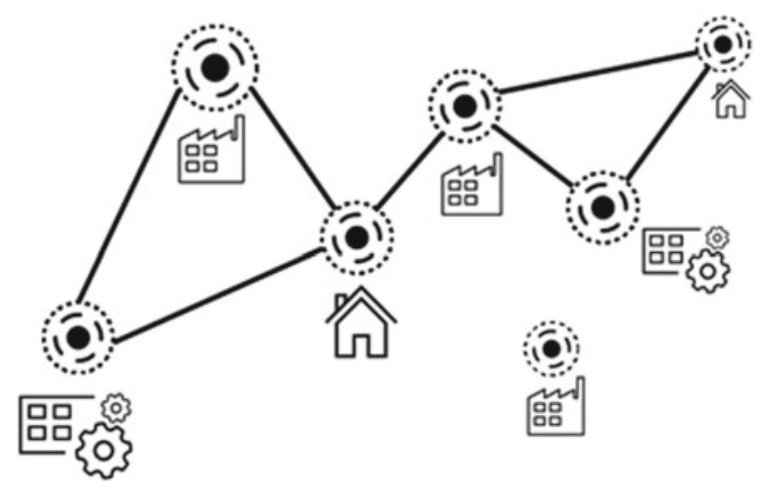

Fig. 4 The structure of the production unit of Distributed Economies
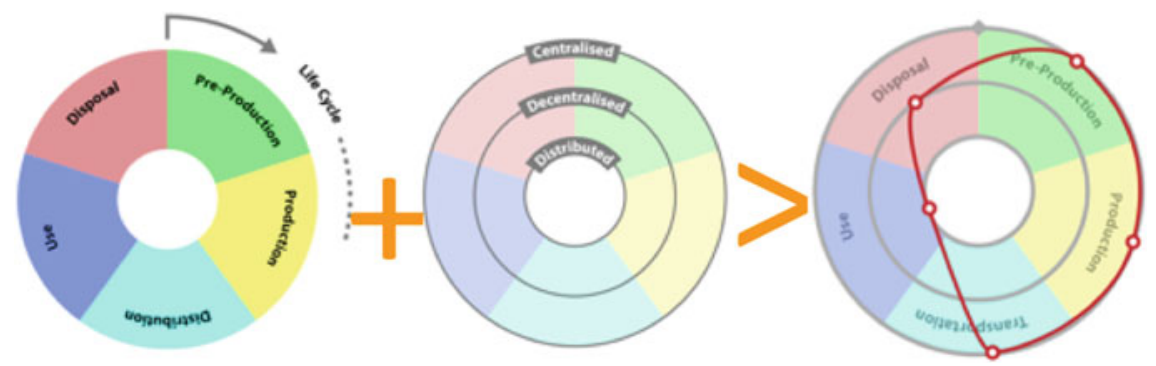

Fig. 5 Example of how a system should be characterized according to how Distributed/Decentralized/Centralized it is in its various life cycle stages

When compared to the Centralized approach, Distributed Economies is a promising offer model for enhancing cohesion to the same goals and more equitable distribution of power at a local level, distributing the activities based on expertise, resource availability and accessibility. Furthermore, these flexible units may have less emphasis on economic growth and more on the achievement of well-being. Therefore, its adoption implies a rupture to the unsustainable foundations of neoclassical economics, which is often driven by the idea that large-scale production makes better economic sense.

It is useful to observe, furthermore, that Distributed Economies (DE) is nothing new. What we have experienced over the course of decades has been and is a process of centralization, especially in industrialized countries. For example, preparing a meal at home is a distributed activity with its home-based production units (ovens, etc.). Nevertheless, even in this case, we may observe an evolution towards a life cycle centralization (in industrialized and emerging contexts): to cook we buy electricity/gas from the main grid (centralized), while in the past we collected nearby biomass (distributed, though with highly toxic combustion fumes); we can purchase food in a supermarket (centralized), while in the past much was cultivated in our 
gardens or bought from neighbourhood shops (distributed); finally, nowadays we can buy "almost ready meals" (centralizing most cooking activities).

Furthermore, DE already exists in many low- and middle-income contexts. In Kenya, for instance, according to the International Labor Organization, 90\% of businesses are informal, which would mean that a large percentage of the population is familiar with the distributed and networked nature of the informal sector. Such a population could already be familiar with the open and networked relationships that S.PSS and DE offer [67]. Hence, Sustainable Distributed Economies (S.DE) need to be seen not as a return to the past, but as a transition towards socially, environmentally, economically and technically advanced sustainable distributed economies.

\section{Practical Implications of DE in Various Fields}

We may identify different types of Distributed Economies (DE). Below is a classification organized in two groups:

Hardware/natural resource-based DE:

- Distributed energy Generation (DG),

- Distributed Food production (DF),

- Distributed Water supply/management (DW)

- Distributed Manufacturing (DM).

Knowledge/information-based DE:

- Distributed Software development (DS),

- Distributed Knowledge generation (DK),

- Distributed Design (DD).

These DE types are described in the following sections.

\subsection{Distributed Design (DD)}

A Distributed Design (DD) system is an open design system where solutions are conceived and/or developed by a small-scale design unit, e.g. one person/computer being the end-user or located nearby the end-users, whether individuals, entrepreneurs and/or organizations/institutions. If the small-scale production units are also connected with other DD (e.g. to share the open design technical drawings), they become a Distributed Design Network (DDN), which may in turn be connected with nearby, similar networks. If properly designed, they are promising to promote locally based sustainability, i.e. Sustainable Distributed Design (S.DD) systems. Through participatory design practices in the context of digital technologies, 
such as open design and crowd-design [19], designers can access widely dispersed or demographically segmented user groups and suppliers, engaging them directly to contribute with ideas and solutions, and encouraging them to engage in the outcome configuration. In this way, the development of a new product, service or ProductService System can be done by laypeople, prosumers, producers, creative communities, experts in various fields, designers and companies, or even by the interaction between these groups [18]. The collaboration between the people involved in the development of these projects can occur through crowd-based platforms, FabLabs, makerspaces, hackerspaces, or iteratively between these spaces [15].

\subsection{Distributed Manufacturing}

Distributed Manufacturing (DM) can be described as a production system made of small-scale manufacturing units equipped with physical and digital technologies, which enable the localization of manufacturing facilities and comprehensive communication between all supply chain actors in order to facilitate customer-oriented production [49]. Key DM features can be summarized into three categories: the localization of manufacturing units, the application of physical and digital technologies, and the customer orientation $[7,34,61]$. The localization of manufacturing units addresses the proximity between manufacturing facilities (e.g. factories, workshops, personal fabrication labs or makerspaces, in-house and in-store suites, mobile manufacturing units, etc.) and end customers and/or manufacturing resources. The application of physical and digital technologies refers to hardware, tangible manufacturing equipment needed to produce products (e.g. 3D printers, laser cutters, Computer Numerical Control (CNC) routers) and the application of computer systems and the use of the Internet (e.g. Industry 4.0, Cloud Computing, Internet of Things, ICT, etc.) used to collect and process data and enable communication between key actors. The customer orientation refers to the level of product or service customization (e.g. mass customization, personalization, bespoke production, etc.) and the level of customer involvement in design and production processes.

Implementation of DM brings multiple benefits for companies and their customers, including companies' resilience to changes in market demand [51], enablement of personalized production [32], facilitated movement and relocation of manufacturing facilities [61], reduction of supply chain actors [4], and many more. However, the transition towards DM requires companies to change organizational mindset [8], adopt new ways of managing business processes [47] and invest in new manufacturing and communication technologies [4]. 


\subsection{Distributed Energy Generation (DG)}

Decentralized and distributed energy generation systems (DG systems) are typically powered by renewable energy sources. These include solar, wind, small hydro, biomass, biogas and geothermal power.

There is no consensus on a shared definition of decentralized generation and distributed generation [22]. For some authors, these two terms are synonymous [33]. For others, the difference is that in decentralized systems, the energy generation units have no interactions with each other $[2,36]$. At any rate, from a technical perspective we can distinguish between $[21,65]$ :

(a) Stand-alone energy systems: these are off-grid systems, thus not connected to each other or to the main grid;

(b) Grid-based systems: these are energy generation systems which supply power at a local level, using local-wide distribution networks [52].

DG systems are associated with a range of potential sustainability benefits [21, 65]:

- From the economic perspective, DG systems are characterized by lower transmission costs for remote regions and lower energy prices in the long-term compared to centralized systems [48]. They can also enhance the flexibility and resilience of the system [31]. A system can easily cope with individual failures (i.e. fault in an energy generation unit) since each energy-using node can be served by multiple energy production units. DG systems require relatively low investments, making it easier for small economic entities such as single individuals and/or local communities to become prosumers (consumers but also producers of the energy).

- In relation to the environmental aspects, the use of renewable and locally available energy sources results in a lower environmental impact compared to the use of fossil fuels (and the related extraction, transformation and distribution processes) [58]. Moreover, local energy production reduces the energy distribution losses that characterize centralized systems.

- Regarding the socio-ethical dimension, the fact that DG systems are relatively easy to be installed and managed (and thus enable users to become prosumers) fosters the process of democratization of energy access, thus enhancing community selfsufficiency and self-governance [14]. Additionally, being locally distributed, they can lead to an increase in local employment (e.g. in relation to installation and maintenance activities) and thus dissemination of competences, which can foster local economies.

However, despite their potential benefits, there are also some barriers to be taken into consideration (for a more detailed discussion see [65], Sect. 5): technical (e.g. resource availability, skill requirement for design and development), economic (e.g. users' purchasing power and spending priorities, energy pricing, incentives), institutional (e.g. policy and regulations), socio-cultural (e.g. norms and value system, behavioural or lifestyle issues), and environmental (e.g. impact on ecosystems and wildlife). 
An example of Distributed Energy Generation is the solution offered by IBEKA, a non-profit organization operating in Indonesia. IBEKA provides hydro mini-grids to communities. This includes the design and installation of the energy generation plant as well as support to enable the local community to manage the plant. IBEKA sets up a community-managed enterprise to run the system and trains it on how to operate, maintain and manage it. The grid-connected system allows communities to sell surplus energy to the national energy supplier. Revenues cover operation, maintenance, loan repayments and a community fund. End-users pay according to a tariff which could be based on a pay-per-energy consumed (meter) or an agreed amount of energy per day.

\subsection{Distributed Water Supply/Management}

A Distributed management system of Water (DW) is a small-scale management unit, located by or nearby the end-users, whether individuals, entrepreneurs and/or organizations/institutions. If the small-scale Water supply/management unit (DW) is also connected with other DWs (e.g. to share the water surplus), they become a Distributed Water supply/management Network (DWN), which may, in turn, be connected with similar networks nearby. If properly designed, they have potential to promote locally based sustainability, i.e. Sustainable Distributed Water supply/management (S.DW) systems. An example of a Distributed Water supply/management (DW) system is the shift from a centralized urban water supply to distributed access to clean groundwater.

Compared with water supply/management systems based on centralized systems, distributed systems are smaller in scale. In structure, the relationship between production units is more equal. It is also more flexible and proactive; compared to the central type, the production unit of the distributed system is closer to the user and more open, which can motivate users to actively participate and develop customized solutions to effectively meet individual needs [68].

For example, P1MC is a charity project initiated by the Brazilian NGO ASA in early 2000 to help residents of the arid regions of north-eastern Brazil to build home rainwater storage facilities. P1MC abandoned the traditional water tank product sales model, but supported local villagers to build their own reservoirs, provided training on routine maintenance methods and provided follow-up technical support. This model of 'collaborative construction' plus 'services and training' has a significant role in promoting project implementation in poor areas. Through professional planning and design, local organizations are encouraged to collaborate with individuals, significantly reducing the cost of building and operating hardware facilities and making local water supply solutions more flexible and agile. 


\subsection{Distributed Food Production (DF)}

Distributed Food production (DF) is a small-scale value-added unit (production/service) associated with food, located by or nearby the end-users, whether individuals or organizations. If the small-scale Food production units (DF) are also connected with other DF (e.g. to share food overproduction), they become a Distributed Food production Network (DFN), which may, in turn, be connected with similar networks nearby. If properly designed they have potential to promote locally based sustainability, i.e. Sustainable Distributed Food production (S.DF) systems.

Centralized food systems evolved along with the advances of the industrial revolution, adopting production and consumption practices based on industrial, mass production logic, that is, introducing elements that aim for system optimization and production efficiency, prioritizing financial gain over quality of food produced. In a period of little more than 200 years, in order to guarantee the expansion of the agricultural frontier and the volume of food production, agro-industrial practices have progressively been adopting mechanization, introducing chemical substances and promoting genetic modification as support pillars of the system. This has put the survival of millenary practices and traditions that revolve around food at risk, without taking into consideration the impact of such practices on the natural and social systems that sustain it, resulting in the consequent socio-environmental degradation of the planet.

Alternatives as Distributed Food production encompass a comprehensive set of ideas that have put into practice the diffusion of community networks and the quest for small-scale and flexible sustainable solutions, making use of local resources. Initiatives include Experiential Agribusiness, Community Supported Agriculture, Urban Farming and the Slow Food movement.

Experiential Agribusiness is based on the offer of gastronomic experiences as a value proposition. It can be considered a decentralized, small-scale system that appropriates traditional food production techniques and cultural practices, reconfiguring new gastronomic propositions strongly influenced by user experience under the name of food design. Community Supported Agriculture focuses on the production of high-quality foods for a local community, often using organic or biodynamic farming methods and a Decentralized or Distributed structure. It connects the producer and consumers within the food system by allowing the consumer to get involved in the different activities related to the harvest of a certain farm or group of farms. Urban farming is the practice of cultivating, processing and distributing food and the raising of animals for food and other uses within and around cities and towns. It takes advantage of vacant and underutilized private or public spaces within the city and the suburbs that might have a potential use for farming purposes. Slow Food is a global movement present in more than 150 countries. It is a reference in debates on biodiversity, local food communities and genetically modified food [3]. It was initiated with the aim to protect regional traditions, good food, gastronomic pleasure and a slow pace of life from the perceived domination of agribusiness, supermarkets and fast food chains. 


\subsection{Distributed Software Development (DS)}

Distributed Software development (DS) is a small-scale production unit (i.e. a computer is the basic hardware for such production), located by or nearby the end-users, whether individuals, entrepreneurs and/or organizations/institutions. If the DS small-scale production units is also connected with other DS (e.g. to share information, open data or open code), they become a Distributed Software Network (DSN), which may, in turn, be connected with similar networks. If properly designed, they hold promise to promote locally based sustainability, i.e. Sustainable Distributed Software development (S.DS) systems. A well-known example of a Distributed production of Software (DS) is the shift from proprietary software to open-source software 'Linux'.

\subsection{Distributed Production of Knowledge (DK)}

A Distributed production of Information/Knowledge (DK) system is a small-scale production unit (i.e. a computer is the basic hardware for such production), located by the end-users or peer-to-peer connected with the end-users, whether individuals, entrepreneurs and/or organizations/institutions. If the DK small-scale production unit is also connected with other DK (for example, to share open information and data), they become a Distributed Knowledge generation Network (DKN), which may, in turn, be connected with similar networks nearby. If properly designed, they hold promise to promote sustainability on a multilocal level, i.e. Sustainable Distributed Knowledge generation (S.DK) systems. A well-known example of Distributed Information/Knowledge generation is the shift from the traditional encyclopaedia to the open encyclopaedia 'Wikipedia'. In fact, the LeNS Learning Network on Sustainability of HEIs could be classified into this category.

\section{Alternative System Configurations}

\subsection{Stand-Alone Configurations}

A stand-alone DE configuration occurs in those systems characterized by the use of either distributed or decentralized production units, without any local delivery system (network) with nearby customers and/or production units. These isolated production units are run by and for the user, either by an individual or an enterprise/organization. A Stand-Alone Distributed system is an isolated production unit by the end-user, while a Stand-Alone Decentralized System is an isolated production unit reached by near-by customers to benefit from the outcomes (of the production unit) (see Fig. 6 below). 


\subsection{Network Configurations}

There are four types of Network Configuration, as described below:

- A Centralized Network System is a network of production units far from the user with an extensive delivery system for various forms of resources (physical and/or knowledge-based) to individuals or enterprises/organizations distributed in a large-scale area such as a state/s, country/ies, continent/s or worldwide (see Fig. 6 below).

- A Decentralized Network System is production with a local delivery system (network) for various forms of resources (physical and/or knowledge-based) to nearby individuals or nearby enterprises/organizations (Fig. 6).

- A Distributed Network System is a network of production units run by the user, either an individual or an enterprise/organization (Fig. 6), sharing various forms of resources (physical and/or knowledge-based) locally with nearby individuals and/or organizations.

- A Hybrid network system is a network of production units that consists of two or more types of centralized, decentralized or distributed network systems (Fig. 6).

Beyond these four configurations, there can also be a Network of Networks, which are either centralized, distributed or decentralized production units or local networks connected to other networks to share various forms of resources (physical and/or knowledge-based) (Fig. 6).

Finally, a DE can also be connected to a Centralized Network. In this case, either distributed or decentralized production units or local networks are connected to a Centralized Network to share various forms of resources (physical and/or knowledgebased) (Fig. 6).

\subsection{Summary and Examples of System Configurations}

Figure 6 visually summarizes the main system configurations described in the previous section.

The following table gives examples from the different DE classifications for these alternative system configurations (Table 2).

\section{Main Drivers and Win-Win Benefits of DE}

Table 3 presents a wide range of win-win benefits of DE according to the three dimensions of sustainability [56]. Changes in customer behaviour and demands, including the quest for greater well-being and more democratic practices, are opening opportunities for a wider adoption of Distributed Economies. The proximity between 


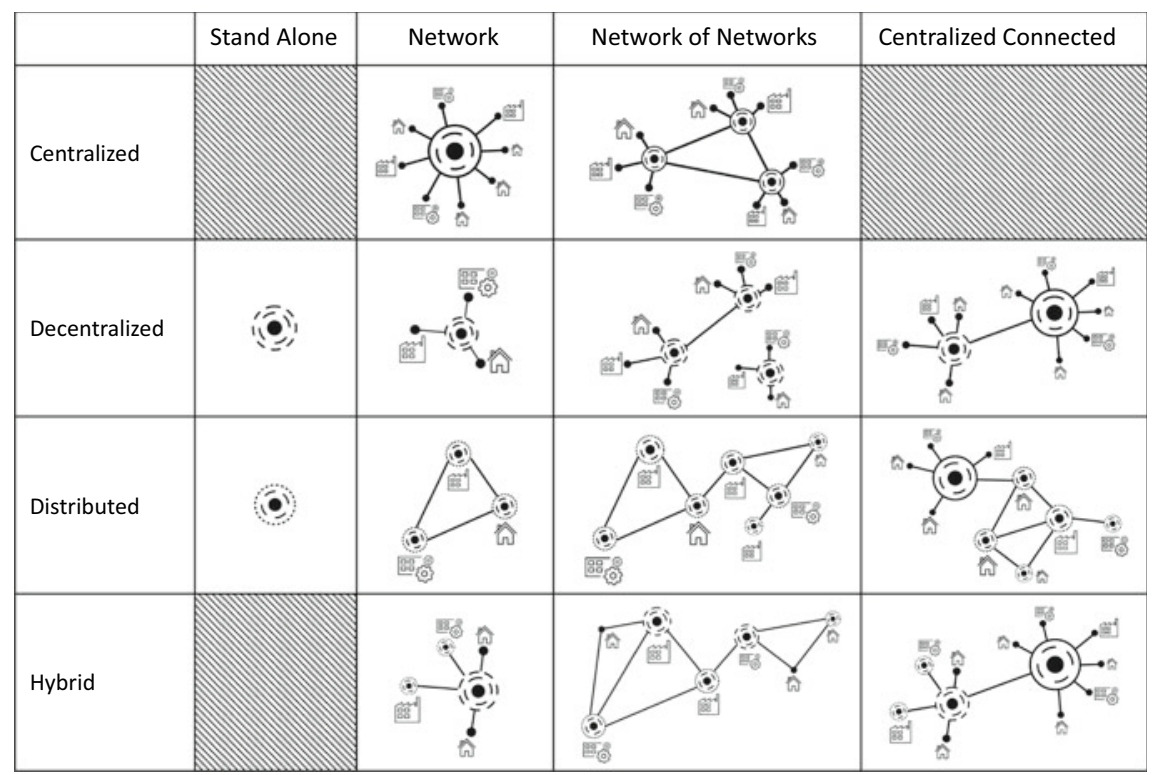

Fig. 6 Possible production/delivery system configurations

producers and consumers enables the provision of solutions with a better fit to local needs. By re-connecting people and producers, Distributed Economies also provide an opportunity for poverty alleviation, with people providing for their needs in alternative ways. Various authors [16,31] argue that DE offers advantages in the pursuit of social diversity, respect for local culture, increased local quality of life and collective spirit, and focus on regional assets expanding the bargaining power for local actors beyond the maximization of social capital.

Some of the main economic drivers to adopt DE characteristics include the growing interest in customization and the reduction of logistics, lead time and labour costs due to shorter distances. In addition, the embedded characteristics of DE enable more collaborative design and production, with optimal distribution and use of resources. It is aligned to the expectations of a young generation that is increasingly in search for jobs with more freedom and creativity.

Emerging technologies have also opened new avenues and opportunities to implement DE. The possibilities provided by technologies such as IoT (Internet of Things), AI (Artificial Intelligence) and digital fabrication (such as Additive Manufacturing technologies), have aligned with a growing level of internet access and broader options for communication technologies. This has opened new avenues for merging digital and physical technologies, resulting in more flexible and agile manufacturing/services as well as knowledge sharing approaches. 


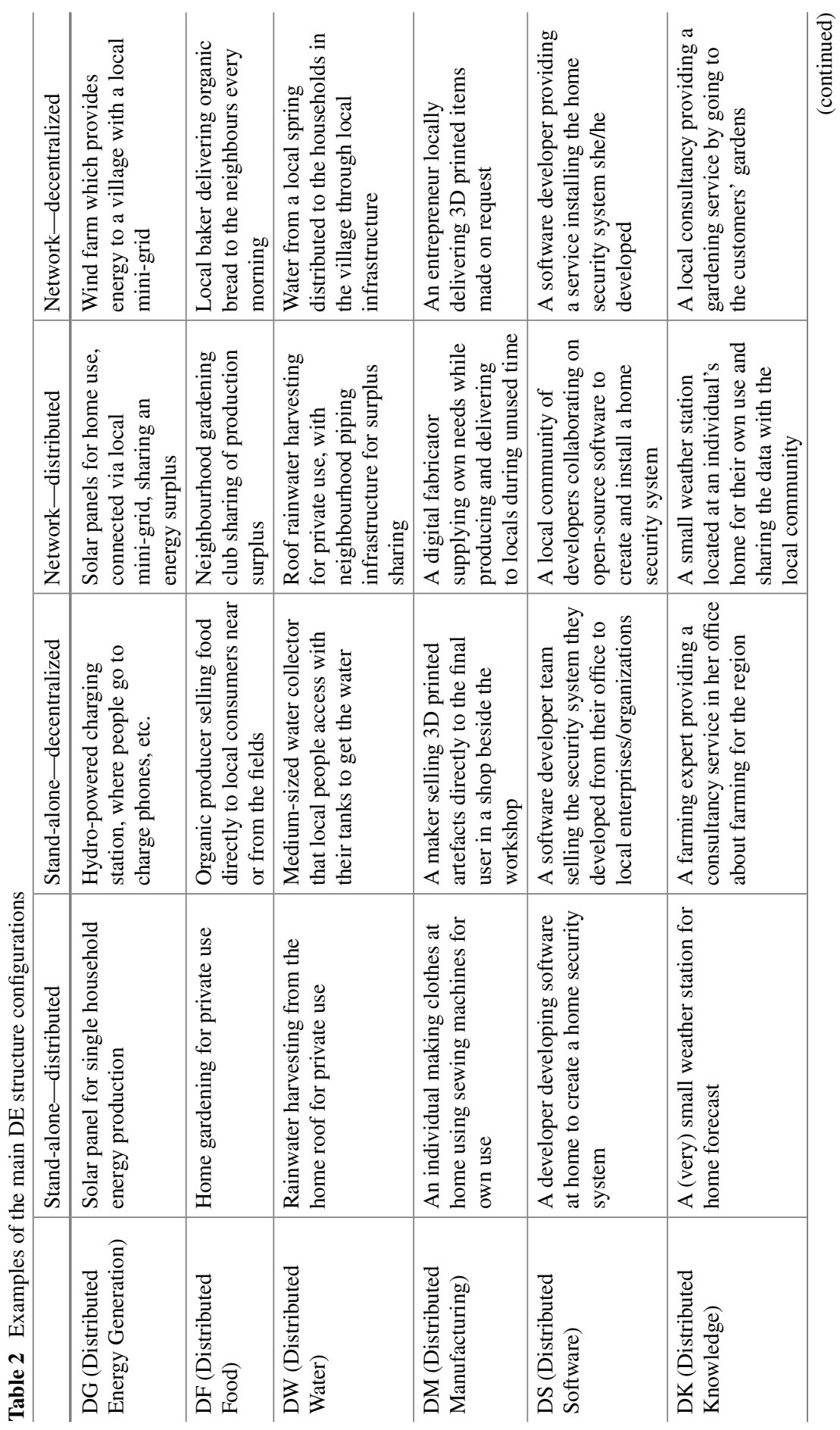




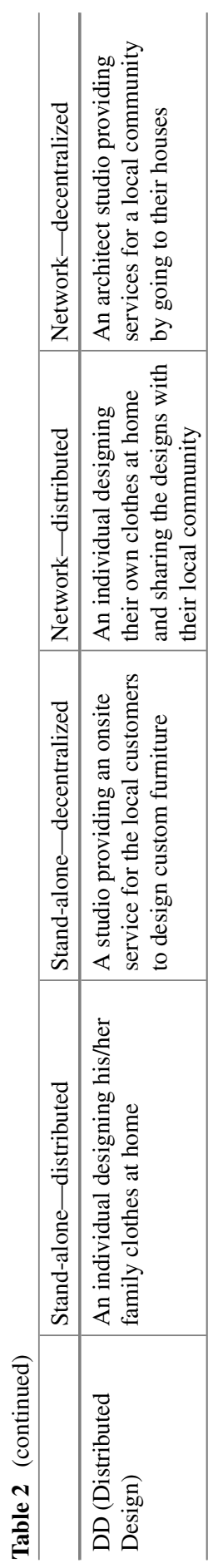


Table 3 Main Win-Win Benefits of DE

\begin{tabular}{|c|c|c|}
\hline Social benefits & Environmental benefits & Economic benefits \\
\hline $\begin{array}{l}\text { - Fosters a culture of mutual } \\
\text { help and empowerment, } \\
\text { enhancing the social } \\
\text { resilience of the system; } \\
\text { - Fosters higher } \\
\text { socio-economic equity, } \\
\text { offering more opportunity } \\
\text { to marginalized people, thus } \\
\text { accepting diversity; } \\
\text { - Encourages the sharing of } \\
\text { knowledge and skills, } \\
\text { providing a better } \\
\text { environment for wide } \\
\text { competence building; } \\
\text { Values local culture, } \\
\text { knowledge and capabilities } \\
\text { by using local skills and } \\
\text { native knowledge, enabling } \\
\text { higher customer/user } \\
\text { involvement in the design } \\
\text { process; } \\
\text { - Promotes social cohesion } \\
\text { among local stakeholders, } \\
\text { with a better cultural fit of } \\
\text { products/services, creating } \\
\text { meaningful and long-lasting } \\
\text { relationships with } \\
\text { customers, promoting } \\
\text { mutual trust at the local } \\
\text { level. }\end{array}$ & $\begin{array}{l}\text { - Enables a shift towards a } \\
\text { circular economy, making } \\
\text { easier the collection of } \\
\text { products at the end of their } \\
\text { life cycle due to shorter } \\
\text { distances; } \\
\text { - Reduces environmental } \\
\text { impact due to shorter } \\
\text { distances, increasing system } \\
\text { efficiency, with a decrease } \\
\text { in the demand for resources } \\
\text { and, at the same time, more } \\
\text { emphasis on the use of } \\
\text { renewable resources and } \\
\text { conserving resources; } \\
\text { - Increases the possibility to } \\
\text { prioritize the environment } \\
\text { over pure financial gains as } \\
\text { users/clients can keep direct } \\
\text { contact with the } \\
\text { environmental impacts } \\
\text { resulting from their choices; } \\
\text { - Delivers a higher rate of } \\
\text { shared services and } \\
\text { resources, leading to better } \\
\text { resource use and } \\
\text { democratization of access to } \\
\text { resources. }\end{array}$ & $\begin{array}{l}\text { - Enables better fulfilment of } \\
\text { local needs, allowing } \\
\text { on-demand production and } \\
\text { reduction of marketing costs } \\
\text { due to customer proximity; } \\
\text { - Provides a higher level of } \\
\text { customization and enables } \\
\text { faster delivery of } \\
\text { product/service changes; } \\
\text { - Features shorter, more } \\
\text { flexible and smaller supply } \\
\text { chains, with sharp reduction } \\
\text { in logistics costs, lead-time, } \\
\text { waste and capital } \\
\text { investment; } \\
\text { - Enables better monitoring } \\
\text { of product performance, } \\
\text { with higher local control } \\
\text { over production; } \\
\text { Valorizes the local } \\
\text { economy, integrates local } \\
\text { competencies and } \\
\text { infrastructure into the } \\
\text { design process, increasing } \\
\text { the bargaining power of } \\
\text { local providers and } \\
\text { encouraging open source } \\
\text { innovation. }\end{array}$ \\
\hline
\end{tabular}

\section{Potential Unsustainability of DE}

'Distributed' does not automatically mean 'good' or anti-centralized, and these concerns are immediately apparent in the most extensive online peer-to-peer platforms, from sharing of services to social media [38, 40, 54, 59]. Even when people are seen as 'members of communities' socially connected to each other (compared to being mere providers of physical labour in a factory), they have nevertheless become providers of data that is sold by centralized media giants to other parties for profit. Individuals acting within these platforms do not become part of collective local economies, nor is their resilience necessarily enhanced by their participation.

As the notion of Distributed Economies emerged from Lund University's International Institute for Industrial Environmental Economics in the mid 2000s, IIIEE publications from that time have helped clarify what it is we do not want in our current global mass production-consumption system by emphasizing DE [31, 41]. The negative characteristics of 'centralization' discussed in this literature still hold 
true for products, services or platforms that appear to be decentralized, distributed and peer-to-peer, and analyses must account for this. Table 4 summarizes these and other main potential unsustainabilities of DE.

The shift to a network society has not yet been accompanied by a generalized knowledge of how to govern ourselves in horizontal networks that embed marketoriented, public-sector-oriented and civic-society oriented actors and actionsparticularly when trying to keep ecological impacts in mind. Decentralizing and distributing too easily ends up as more business-as-usual. "[L]ocal actors' possibilities to have ownership and control over their immediate economic environment" may be strengthened in appearance, while weakened in operation [41]. It is thus essential to pay attention to what remains centralized, when limited conceptions of market value predominate, and when discussions on the nature of economic collaboration is depoliticized. Communities that strive to repoliticize the discussion on decentralizing, from Transition Towns to indigenous land defenders to open design groups working on sustainable solutions, make visible what is 'centralized' and why it is undesirable, and they actively prototype and prefigure new modes of production. By examining their examples, and how they interplay with mass production and consumption from the 'orthodox economy' (see Sect. 1), we see that characteristics such as standardization and modularity, for instance, are still useful, but useful for community autonomy and resilience, not for financial profit for a selected few.

Table 4 Potential unsustainabilities of DE

\begin{tabular}{l|l}
\hline Potential environmental unsustainabilities & Potential social unsustainabilities \\
\hline $\begin{array}{l}\text { Large-scale centralized production units } \\
\text { could optimize resource consumption and } \\
\text { emissions (per production outcome) }\end{array}$ & $\begin{array}{l}\text { DE production units are not necessarily } \\
\text { empowering local economies and well-being }\end{array}$ \\
\hline $\begin{array}{l}\text { In centralized production units, labour } \\
\text { practices could be more specialized } \\
\text { ("expert"), i.e. optimizing resource }\end{array}$ & $\begin{array}{l}\text { DE production units, particularly the increase of } \\
\text { do-it-yourself, could at the same time decrease } \\
\text { employment, as far as doing something by } \\
\text { consumption and emissions (per production } \\
\text { outcome) }\end{array}$ \\
$\begin{array}{l}\text { DE production units are not necessarily reduces the opportunities to employ } \\
\text { (designed) with a low environmental impact } \\
\text { le.g. to use renewable resources) }\end{array}$ & $\begin{array}{l}\text { DE production units could be used merely as a } \\
\text { strategy to outsource locally, without proper } \\
\text { care for safety standards and the quality of life } \\
\text { in workplaces }\end{array}$ \\
$\begin{array}{l}\text { DE outcomes do not necessarily have a low } \\
\text { environmental impact }\end{array}$ & $\begin{array}{l}\text { An increase in the amount of local production or } \\
\text { services may jeopardize social habits or routines }\end{array}$ \\
\hline $\begin{array}{l}\text { DE practices that involve increased } \\
\text { digitalization may contribute to greater } \\
\text { volumes of e-waste, increased electricity } \\
\text { consumption, greater embodied energy of } \\
\text { electronic system components and increased } \\
\text { consumption of scarce resources such as rare } \\
\text { earth metals }\end{array}$ & $\begin{array}{l}\text { Local production or services may require expert } \\
\text { knowledge and/or material or cultural resources } \\
\text { that are not locally available }\end{array}$ \\
\hline
\end{tabular}


Especially in the last five to ten years, internet-enabled, open, peer-to-peer connectedness has enhanced our ability to participate and radically distribute tasks and activities. However, it has also weakened our physical and mental health, accelerated throughput of e-waste, increased our global need for energy, further marginalized the already marginalized, and threatened our very democracies. It appears, then, that we need to not only re-visit the literature but continually update our alternative conceptualizations of the economy and its role in structuring our relationship to the living earth and webs of life. For more resilient communities, the DE concept has emphasized good environmental performance, local people's preferences, quality of life and well-being [30], while particularly examining privileged regions in northern Europe. The Stockholm Resilience Centre has emphasized how humans and nature are intertwined in complex social-ecological systems, where resilience-building needs to nurture diversity, combine different types of knowledge for learning and create opportunities for self-organization [26], while remaining within the paradigm of 'development'. From the perspective of post-development and post-coloniality, acknowledging that global inequities are only increasing, Escobar [23] and others have emphasized plurality, community autonomy and self-determination.

To conclude, despite its potential unsustainabilities, DE still stands as a useful framework for understanding how we want to shape our local economies, even within a rapidly transforming, global environment with many industrial and post-industrial trajectories.

\section{Understanding DE from Different Contexts}

\subsection{A Brazilian Perspective}

The service sector is the largest component (70\%) of the Brazilian national Gross Domestic Product (GDP). However, there is an uneven development pattern of the sector across the country. Service activities are concentrated in the same large poles with a North-South divide: the South concentrates the most dynamic sectors and providing greater diversity of services, as well as larger sizes of firm, i.e., greater economies of scale. The North, particularly in the northeast region, shows lower diversification of services and an intense concentration of the 'Public Administration' sector [10]. The inequalities in the country are particularly relevant when it comes to access to basic sanitation, sewage treatment and potable water [63]. The provision of services on items such as water and electricity still follow a poorly effective and highly centralized approach. According to Lepre and Castillo [35], in the Northeast region, one of the poorest in the country, many communities still live in the dark and distant from sources of drinking water. Whilst Brazil is one of the world's leading producers of hydroelectric power, with a current capacity of about 260,000 megawatts, the most relevant initiatives in the energy sector are those directed towards large-scale facilities [63]. 
In order to reverse this situation, there is a growing number of community-based initiatives, start-ups and NGOs that are investing in more decentralized or distributed approaches, deploying and implementing water and energy solutions with small and flexible localized units. New regulation is stimulating the construction of smallscale hydroelectric plants, which in Brazil are defined as those with a capacity of 5 to $30 \mathrm{MW}$ and an area of reservoir limited to $13 \mathrm{~km}^{2}$. From 331 small-scale plants in 1999, the country reached 1129 in 2019, according to ABRAPCH [1].

Industry in Brazil follows a Distributed Economy in those sectors with lower demands on technology or with lower demands on capital investment, enabling individuals or small companies to start their own business. This is the case in the clothing and textile sector, for instance. Brazil is a country where all stages of the clothing supply chain can be found within the country borders, from fibre production to semi-processed products (yarn and fabrics with their finishing processes) and final products. Industrial clusters in this sector are good examples of decentralized or distributed approaches to the economy. These clusters are composed of a variety of company sizes and types, including cooperatives and/or craftworkers, organized in close proximity to customers and suppliers, contributing to optimize their production and logistic processes.

In contrast, in the agricultural sector, there is a mix of centralized, decentralized and distributed approaches, operating simultaneously across the supply chain. Part of the expansion of the agribusiness sector occurred at the expense of the environment, including the Amazon. It is quite common that investment in this sector prioritizes large-scale farms, huge silos that often stock grains for more than a year waiting for better international prices, and large ports with correspondent large ships to transport commodities across the oceans. However, in this same agricultural sector there are federal, state and municipal initiatives directed towards family agriculture, which is highly distributed in its essence, with around 800 thousand rural inhabitants being assisted with credit, research and extension programmes [42]. These small-scale local farmers supply food to rural communities, schools and on urban street markets, in direct contact with their final consumers.

\subsection{A Chinese Perspective}

In China, sustainable development has become a social consensus. Meanwhile, the relevant concepts of sustainable development have been widely recognized at all levels of society, and these concepts are consistent with the principles of the DE to a certain extent. On the other hand, China can benefit from its development in the Internet field, and the promotion and implementation of a distributed economy are possible. We can see that technological advances are rapidly affecting and changing China's consumption patterns. Manufacturing, energy, water, food and information/knowledge production industries are showing decentralized/distributed trends and potentials to varying degrees and will bring challenges to the mainstream economic model. However, it should also be noted that China's current development 
success has actually relied on a central development model. Therefore, for a long time to come, in China, the status of this central economic development model will remain unshakable. All stakeholders committed to promoting China's sustainable transformation need to think carefully and rationally about the role of the distributed economy.

We also need to acknowledge that the sustainable development of various regions in China is not balanced, and there is a clear difference in sustainable development between second/third-tier cities and first-tier cities (Beijing, Shanghai, Guangzhou and Shenzhen). Especially in terms of sustainable production and consumption, although China has been actively promoting cleaner production and green consumption lifestyles, China's economic development mode is still in a relatively extensive stage. Consumption and high pollutant emissions still exist. On the other hand, the public's awareness of green consumption and production needs to be further improved. From another perspective, this can also be seen as an excellent opportunity for a distributed economy to realize its sustainable potential. As a large and dynamic country, China is likely to have extensive and in-depth development and actions in many areas of the distributed economy in the future [68].

\subsection{A Finnish Perspective}

In Finland, certain concepts related to a more sustainable society have become prominent, which are grounded on principles that are compatible with those of Distributed Economies. This is not surprising, as DE was developed in the neighbouring country of Sweden, and much of northern Europe has experienced the negative economic effects of manufacturing that has moved offshore to regions with cheaper labour and raw materials while recognizing that our consumption patterns are also outsourcing pollution and bad working conditions to these regions. In Finland, this was especially visible in the fashion and textiles sector. DE principles related to revitalizing the economy, regional collaboration on high-value-added, high-quality products using local raw materials and resources (knowledge, manufacturing capabilities and skills), are therefore easily applied. The most popular economic revitalization concept that robustly embeds sustainability considerations in Finland is that of a Circular Economy (or Circular Bio-Economy). In this vision, local resources related to biomass circulate as biological nutrients in the organic cycle of the economy, adding value where possible through upcycling and cascading. Stakeholders, companies, research institutes, investors and customers, collaborate in production, research and innovation, in order to diversify the Finnish economy and strengthen its resilience. Therefore, Finland as a region with a particular industrial history would find many aspects of Distributed Economies strategically attractive. 


\subsection{An Indian Perspective}

Pre-colonial industrialization in India was largely based on distributed, village-based economies, even for global trade in manufactured goods like textiles and handicrafts. However, colonization and the subsequent post-colonial industrialization created a push towards centralized global and monopolistic manufacturing systems which denuded the network of local production economies. Over the last few decades, there has been cross-sectoral movement back towards distributed economies motivated mainly by issues of livelihood generation and economic empowerment by tapping into urban markets to develop opportunities for rural economies.

Distributed production systems were revived on a large scale through cooperative dairy companies like Amul and traditional food companies like Lijjat Papad, formed in the late 1940s and early 1950s, which have managed to develop vast networks of village-based production units. These companies set the template for distributed economies which, over the past two decades, have developed in diverse sectors like fashion and textiles, handicrafts, food processing, energy production and water management among others, resulting in tens of thousands of people being financially empowered and in a shift towards more environmentally and socio-ethically conscious consumption patterns, as well as a growing interest in traditional and indigenous aesthetics and lifestyles.

In urban India, distributed economies have been powered by technological aggregator platforms mainly in the service sector in industries ranging across design and architecture, construction and maintenance, transportation, food and beverages and hospitality. Environmentally sound practices are increasingly being incorporated into these platforms.

While these developments are varied and exciting, their theorization within the discourse of distributed economies remains at a nascent stage. The challenge will be to understand how these economies function in relation to each other and how they can work within larger economic and ecological systems.

\subsection{A Mexican Perspective}

We can distinguish three important factors in the Mexican economy:

1. Large investments are made by transnational industries that are concentrated in specific states. According to INEGI (National System of Statistical and Geographical Information in Mexico), the manufacturing industry has made the largest contribution to state GDP in Coahuila de Zaragoza, Querétaro, State of Mexico, Aguascalientes, Guanajuato, Puebla and San Luis Potosí, which coincides with the investment plans reported by a survey published by Manufactura MX [37].

2. The traditional production models that have been able to resist Mexico's incursion into global markets are those oriented towards a Distributed Economy. 
3. The informal sector takes an important role, both because of its scale and because it mainly focuses on the satisfaction of local markets, one of the key characteristics of Distributed Economy models.

In Mexico, the industrialization process has focused on development poles in specific geographical areas, which has created impoverished regions where economic activities develop with difficulty. The industrialization process in Mexico has not always been the result of an international state policy; sometimes it has responded to industry push and the changing conditions of the environment [25]. On the other hand, after the entry into force of NAFTA (North American Free Trade Agreement), industrialization has been driven by the creation of global supply chains, where the strategy focuses on opening up to foreign trade [25] and not to the satisfaction of local markets.

The investment plans of the manufacturing sector are settled in eight states (national regions). It is not yet a priority to enter the three special economic zones (EEZs) declared in 2015 by the federal government to boost development in regions with greater social and economic lags in the country, according to the study [37]. This indicates that although there are public policy efforts to generate development poles that move closer to the decentralized model, the investment plans of the companies are oriented towards maintaining a traditional industrialization model. The survey applied to 812 Mexican business leaders nationwide, of large and medium-sized companies from various industries, established in the country, reveals that $55 \%$ of those interviewed are taking their company to a state in Mexico. In 2015, that estimate was 63 percent [37].

However, it is possible to find cases of models closer to distributed economies that respond to the satisfaction of local markets. Nevertheless, they are currently in danger because of public policy trends aimed at impacting global markets. To take one example, the Colonia Morelos neighbourhood in Mexico City is so large that it contains two important boroughs: the Cuauhtémoc and the Venustiano Carranza. It is currently one of the most important areas for drug trafficking, which has made it a violent area; however, its commercial activities dating from the last century (1881) still prevail. At that time, its inhabitants were engaged in the manufacture of shoes, a trade of great tradition and which continues in one of its neighbourhoods, Tepito. Currently, along the principal avenue of that zone, several supply stores related with the manufacture of shoes and bags are established, as well as workshops that offer Product-Service Systems i.e. manufacturing parts of the shoe production process are offered. In other words, shoemakers who do not have sewing machinery, for example, can send their pre-cut pieces to local workshops, which offer sewing services. In this way, finished products are offered in the local Granaditas Market.

In Mexico, local markets are served not only by the formal sector: 76 out of every 100 pesos generated from GDP are produced by $42 \%$ of all formal jobs and 24 pesos are generated by $58 \%$ of informal jobs. Informality in Mexico is widespread and, in particular, much more widespread than in other countries in the region. High informality is worrying because it denotes an inadequate distribution of resources (in particular labour) and an extremely inefficient use of government services, which can 
compromise the country's growth prospects. Mexico's principal challenge would be focused on finding an efficient strategy to turn back to local markets through DE.

\section{References}

1. ABRAPCH (Associação Brasileira de PCHs e CGHs) (2019) Número de PCHs em operação no Brasil. https://abrapch.org.br/faq/numero-pchs-em-operacao-no-brasil/. Accessed 25 Nov 2019

2. Alanne K, Saari A (2006) Distributed energy generation and sustainable development. Renew Sustain Energy Rev 10(6):539-558

3. Andrews G (2008) The slow food story: politics and pleasure. Pluto Press, London

4. Angeles-Martinez L, Theodoropoulos C, Lopez-Quiroga E, Fryer P, Bakalis S (2018) The honeycomb model: A platform for systematic analysis of different manufacturing scenarios for fast-moving consumer goods. J Clean Prod 193:315-326

5. Beltagui A, Kunz N, Gold S (2020) The role of 3D printing and open design on adoption of socially sustainable supply chain innovation. Int J Prod Econ 221:107462

6. Benkler Y (2006) The wealth of networks: how social production transforms markets and freedom. Yale University Press, New Haven, CA

7. Bessière D, Charnley F, Tiwari A, Moreno MA (2019) A vision of re-distributed manufacturing for the UK's consumer goods industry. Prod Plann Control 30(7):555-567

8. Bogers M, Hadar R, Bilberg A (2016) Additive manufacturing for consumer-centric business models: Implications for supply chains in consumer goods manufacturing. Technol Forecast Soc Chang 102:225-239

9. Brede M, de Vries BJM (2009) Networks that optimize a trade-off between efficiency and dynamical resilience. Phys Lett A 373(43):3910-3914

10. Cardoso V, Perobelli F (2014) Evaluation of the structure of the services sector in Brazil: a regional approach, ERSA conference papers ersa14 p 865, European Regional Science Association

11. Carson KA (2010) The Homebrew industrial revolution: a low-overhead manifesto. Booksurge

12. Castells M (2000) The rise of the network society, 2nd edn. Wiley-Blackwell, Malden, MA

13. Ceschin A (2010) A natureza como limite da economia: a contribuição de Nicholas GeorgescuRoegen. Editora Senac São Paulo/Edusp, São Paulo

14. Chaurey A, Krithika PR, Palit D, Rakesh S, Sovacool BK (2012) New partnerships and business models for facilitating energy access. Energy Policy 47:48-55

15. Costa C, Pelegrini A (2018) Design Distribuído: novas práticas e competências para o design pós-industrial. In: Anais do $13^{\circ} \mathrm{P} \& D$ Design. Univille, Joinville

16. Crul M, Diehl JC (2006) Design for sustainability (D4S): a step-by-step approach. Modules, United Nations Environment Programme (UNEP)

17. Daly H (2010) Crescimento se tornou antieconômico. Revista Época Negócios, julho. http:// epocanegocios.globo.com/Revista/Common/0,EMI151601-16381-1,00-CRESCIMENTO+ SE+TORNOU+ANTIECONOMICO+DIZ+HERMAN+DALY+PAI+DA+ECONOMIA+ ECOLOGI.html+PAI +DA+ECONOMIA+ECOLOGI.html. Accessed 27 May 2020

18. De Vere I (2013) Industrial design 2.0: a renaissance. In: International conference on engineering and product design education 5 \& 6, Dublin Institute of Technology, Dublin

19. Dickie IB (2018) Proposition of a reference model of Crowd-design for sustainability. Post Graduation Program in Design [Doctoral Dissertation]. Federal University of Parana, Curitiba, Brazil

20. Dreyer B, Lüdeke-Freund F, Hamann R, Faccer K (2017) Upsides and downsides of the sharing economy: Collaborative consumption business models' stakeholder value impacts and their relationship to context. Technol Forecast Soc Chang 125:87-104 
21. Emili S, Ceschin F, Harrison D (2016) Product-Service Systems applied to Distributed Renewable Energy: a classification system and 15 archetypal models. Energy Sustain Dev 32:71-98

22. Emili S (2017) Designing product-service systems applied to distributed renewable energy in low-income and developing contexts: a strategic design toolkit. PhD Thesis, Brunel University London

23. Escobar A (2018) Designs for the Pluriverse: radical interdependence, autonomy, and the making of worlds. Duke University Press, Durham, US

24. Freeman R, McMahon C, Godfrey P (2017) An exploration of the potential for re-distributed manufacturing to contribute to a sustainable, resilient city. Int J Sustain Eng 10(4-5):260-271

25. Flores Kelly J (2018) México piensa+. Ediciones Felou, Mexico City

26. Folke C (2016) Resilience (Republished). Ecol Soc 21(4):Article 44

27. Gaiger LI (2008) A dimensão empreendedora da economia solidária: Notas para um debate necessário. Otra Economia 11(3)

28. Hawken P, Lovins A, Lovins LH (1999) Natural capitalism: creating the next industrial revolution. Little, Brown, and Company, Boston

29. Illich I (1973) Tools for conviviality. Harper and Row, New York

30. IIIEE (International Institute for Industrial Environmental Economics) (2009) The future is distributed: a vision of sustainable economies. IIIEE, Lund

31. Johansson A, Kisch P, Mirata M (2005) Distributed economies - A new engine for innovation. J Clean Prod 13(10-11):971-979

32. Kaneko K, Kishita Y, Umeda Y (2018) Toward developing a design method of personalization: Proposal of a personalization procedure. Procedia CIRP 69:740-745

33. Kaundinya DP, Balachandra P, Ravindranath NH (2009) Grid-connected versus stand-alone energy systems for decentralized power-A review of literature. Renew Sustain Energy Rev 13(8):2041-2050

34. Kumar M, Tsolakis N, Agarwal A, Srai JS (2020) Developing distributed manufacturing strategies from the perspective of a product-process matrix. Int J Prod Econ 219:1-17

35. Lepre P, Castillo L (2019) The third sector as a vector to foster distributed design and distributed economy initiatives: a case study of inclusive, ethical and sustainable social development in emerging economies. In: Ambrosio M, Vezzoli C (eds) Designing sustainability for all - 3rd LeNS world distributed conference proceedings. Milano, IT, Edizioni Poli.design

36. Mandelli S, Mereu R (2014) Distributed generation for access to electricity: "Off-main-grid" systems from home-based to microgrid. In: Colombo E et al (eds) Renewable energy for unleashing sustainable development. Springer, Heidelberg, pp 75-97

37. Manufactura MX (2016) 8 Estados más atractivos para los industriales. https://manufactura.mx/ industria/2016/04/26/los-8-estados-mas-atractivos-para-la-industria. Accessed 25 Nov 2019

38. Martin M, Lazarevic D, Gullström C (2019) Assessing the environmental potential of collaborative consumption: peer-to-peer product sharing in Hammarby Sjöstad, Sweden. Sustainability 11(1)

39. Mathai MV (2012) Green economy and growth: Fiddling while Rome Burns? United Nations University. http://unu.edu/articles/science-technologysociety/green-economy-and-gro wth-fiddling-while-rome-burns. Accessed 27 Jan 2012

40. McKee D (2017) Neoliberalism and the legality of peer platform markets. Environ Innov Soc Transit 23:105-113

41. Mirata M, Nilsson H, Kuisma J (2005) Production systems aligned with distributed economies: examples from energy and biomass sectors. J Clean Prod 13(10-11):981-991

42. MTE (Ministério do Trabalho e Emprego) (2012) O que é Economia Solidária. http://www. mte.gov.br/ecosolidaria/ecosolidaria_oque.asp. Accessed 14 Oct 2012

43. Mumford L (1934) Technics and civilization. Harcourt, Brace, and Company, New York

44. Murillo D, Buckland H, Val E (2017) When the sharing economy becomes neoliberalism on steroids: unravelling the controversies. Technol Forecast Soc Chang 125:66-76

45. Napier E, Sanguineti F (2018) Fashion Merchandisers' Slash and Burn dilemma: a consequence of over production and excessive waste? Rutgers Bus Rev 3(2):159-174 
46. Niinimäki K, Peters G, Dahlbo H, Perry P, Rissanen T, Gwilt A (2020) The environmental price of fast fashion. Nat Rev Earth Environ 1(4):189-200

47. Pearson H, Noble G, Hawkins J (2013) Re-distributed manufacturing workshop report. EPSRC, UK

48. Peças Lopes JA, Hatziargyriou N, Mutale J, Djapic P, Jenkins N (2007) Integrating distributed generation into electric power systems: a review of drivers, challenges and opportunities. Electr Power Syst Res 77(9):1189-1203

49. Petrulaityte A, Ceschin F, Pei E, Harrison D (2017) Supporting sustainable product-service system implementation through distributed manufacturing. In: The 9th CIRP industrial productservice system conference: circular perspectives on product/service-systems, Denmark

50. Pizzol M (2015) Life cycle assessment and the resilience of product systems. J Ind Ecol 19(2):296-306

51. Rauch E, Dallasega P, Matt DT (2016) Sustainable production in emerging markets through Distributed Manufacturing Systems (DMS). J Clean Prod 135:127-138

52. Rolland S (2011) Rural electrification with renewable energy: technologies, quality standards and business models. Alliance for Rural Electrification, Brussels, Belgium

53. Botsman R, Rogers R (2011) What's mine is yours: the rise of collaborative consumption. Collins, London

54. Rowe PCM (2017) Beyond Uber and Airbnb: the social economy of collaborative consumption. Social Media Soc 3(2):2056305117706784

55. Sachs I (2002) Caminhos para o desenvolvimento sustentável. Garamond, Rio de Janeiro

56. dos Santos A (2018) Theoretical foundations on SPSS and DE: a survey among members of the learning network on sustainability (LeNS). Report on Round 02 of Questioning. Learning Network on Sustainability, Curitiba

57. dos Santos A, Braga AE, Sampaio CP, Andrade ER, Merino EAD, Trein F, Duarte GG, Rosa IM, Massaro JG, Lepre PR, Noronha R, Engler R, Vasques RA, Nunes VGA (2019) Design para a Sustentabilidade: Dimensão Econômica, 1st edn. Editora Insight. v, Curitiba, p 1

58. Schillebeeckx SJD, Parikh P, Bansal R, George G (2012) An integrated framework for rural electrification: Adopting a user-centric approach to business model development. Energy Policy 48:687-697

59. Scholz T, Schneider N (eds) (2016) Ours to hack and to own: the rise of platform cooperativism, a new vision for the future of work and a fairer internet. OR Books, New York

60. Sen A (1999) Sobre ética e economia. Companhia das Letras, São Paulo

61. Srai JS, Kumar M, Graham G, Phillips W, Tooze J, Tiwari A, Ford S, Beecher P, Raj B, Gregory M, Tiwari M, Ravi B, Neely A, Shankar R (2016) Distributed manufacturing: Scope, challenges and opportunities. Int J Prod Res 54(23):6917-6935

62. Stahel WR (1986) Hidden innovation: R\&D in a sustainable society. Science \& Public Policy 13(4):196-203

63. Tundisi JG (2008) Water resources in the future: problems and solutions. Estudos Avançados 22(63) São Paulo

64. da Veiga, J.E. (2005). O Prelúdio do Desenvolvimento Sustentável. In: CAVC, Economia Brasileira: Perspectivas do Desenvolvimento, pp. 243-266. http://www.zeeli.pro.br/Livros/ 2005_b_preludio_\%20desenvolvimento_sustentavel.pdf. Accessed 27 May 2020

65. Vezzoli C, Ceschin F, Osanjo L, M'Rithaa MK, Moalosi R, Nakazibwe V, Diehl JC (2018) Designing sustainable energy for all: sustainable product-service system design applied to distributed renewable energy. Springer, London

66. Vezzoli C (2010) System design for sustainability: a promising approach for low and middleincome contexts. In: International forum Design for Sustainability in Emerging Economies. June 2-5, Autonomous Metropolitan University of Mexico City

67. Vezzoli C, Delfino E, Amollo Ambole L (2014) System design for sustainable energy for all. A new challenging role for design to foster sustainable development http://dx.doi.org/10.7577/ formakademisk.791

68. Xia N, Liu X (2016) The new context of design: research on the sustainability of distributed economy. Zhuang Shi (12) 
Open Access This chapter is licensed under the terms of the Creative Commons Attribution 4.0 International License (http://creativecommons.org/licenses/by/4.0/), which permits use, sharing, adaptation, distribution and reproduction in any medium or format, as long as you give appropriate credit to the original author(s) and the source, provide a link to the Creative Commons license and indicate if changes were made.

The images or other third party material in this chapter are included in the chapter's Creative Commons license, unless indicated otherwise in a credit line to the material. If material is not included in the chapter's Creative Commons license and your intended use is not permitted by statutory regulation or exceeds the permitted use, you will need to obtain permission directly from the copyright holder.

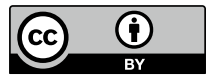

